Aksiologiya: Jurnal Pengabdian Kepada Masyarakat

Vol.5, No. 2, Mei 2021 Hal 255 - 263

ISSN 2528-4967 (print) dan ISSN 2548-219X (online)

\title{
Pelatihan Daur Ulang Limbah Botol Plastik Pada Remaja Di Kota Ternate
}

\author{
Hamidah Rahman', Rosmila Tuharea ${ }^{2}$ \\ 1,2Universitas Muhammadiyah Maluku Utara, Ternate \\ Email : hamidahr42@gmail.com¹,vtuharea@yahoo.com²
}

\begin{abstract}
ABSTRAK
Salah satu sumber pencemaran lingkungan diakibatkan oleh limbah yang tidak dapat dengan mudah terdegradasi di alam, antara lain limbah yang dihasilkan dari minuman kemasan botol plastik. Indonesia adalah negara terbesar kedua yang menghasilkan limbah plastik yang kemudian diketahui sebagian besar terbuang ke laut. Hal ini dapat mengakibatkan pencemaran lingkungan dan terganggunya ekosistem di laut. Tujuan pengabdian masyarakat ini adalah memberikan sosialisasi melalui penyuluhan interaktif kepada siswa di Sekolah Menengah Pertama Muhammadiyah 1 Kota Ternate. Hal ini dimaksudkan untuk memberikan pengetahuan dan sikap yang baik siswa/ remaja dalam menggunakan minuman berkemasan botol plastik. Selain itu kegiatan ini juga untuk memperkenalkan konsep 3R (Reuse, Reduce, Recycle) sedini mungkin ke siswa/remaja. Kegiatan juga mengajarkan keterampilan kepada siswa untuk dapat mengolah limbah botol plastik menjadi karya seni yang berguna. Hasil kegiatan pengabdian masyarakat ini telah berhasil meningkatkan pengetahuan dan sikap siswa terhadap konsep 3R sebesar 37\% dan 40\% berturut-turut. Selain itu pelatihan daur ulang botol minuman kemasan plastik telah meningkatkan keterampilan siswa dalam mengelolah limbah botol plastik menjadi karya seni. Kegiatan ini diharapkan dapat menginisiasi remaja untuk berperan dalam mengurangi pencemaran lingkungan. Program ini direncanakan berkelanjutan dengan sasaran mitra siswa dari sekolah lain dan pada komunitas masyarakat lainnya di kota Ternate.
\end{abstract}

Kata Kunci: Konsep 3R; Plastik, Pencemaran; Remaja.

\section{Training on Recycling of Plastic Bottle Waste for Youth in Ternate City}

\section{ABSTRACT}

One source of environmental pollution is caused by waste that cannot be easily degraded in nature, including waste produced from plastic bottles. Indonesia is the second largest country that produces plastic which was later found to be largerly discharged into the sea. This can cause environmental pollution and disruption of the marine ecosystem. The aim of community service is to provide socialization through interactive counseling to students at Muhammadiyah 1 Junior High School in Ternate. This is intended to provide knowledge and good attitude of students/teenagers in using plastic bottle. In addition, this activity is also to introduce the concept of $3 R$ (Reuse, Reduce, and Recycle) as early as possible to students/teenagers. The activity also teaches students with skills to be able to process plastic bottle waste into useful artwork. The results of community service activities have succeeded in increasing students' knowledge and attitudes about the $3 R$ concept by $37 \%$ and $40 \%$ respectively. In addition, training in recycling plastic beverage bottle has increased students'skills in managing plastic bottle waste. This activity is expected to initiate young people to play a role in reducing environmental pollution. The program is planned to be sustainable with the target of student partners from other schools and other communities in Ternate city.

Key word: Pollution; Plastics; the $3 R$ concept; Teenagers. 


\section{PENDAHULUAN}

Limbah adalah salah satu sumber pencemaran yang dapat mengakibatkan menurunnya kualitas dan kerusakan lingkungan (Rastono et al. 2018). Limbah diartikan sebagai benda yang dibuang, baik yang berasal dari alam maupun dari hasil proses teknologi yang sudah tidak memiliki nilai ekonomis. Meskipun limbah merupakan produk samping atau by product yang dihasilkan dari suatu proses produksi, namun beberapa peneliti berhasil mengubah limbah menjadi produk atau barang yang bermanfaat, antara lain pemanfaatan limbah dari industri konveksi menjadi keset sehingga meningkatkan status ekonomi masyarakat (Ferdiani et al. 2018) dan pemanfaatan limbah hasil pertanian dan peternakan menjadi pupuk kompos (Nurman et al. 2019).

Selain limbah, keberadaan sampah juga masih menjadi masalah yang dapat mencemari lingkungan. Berdasarkan data dari Kementerian Lingkungan Hidup, setiap hari penduduk Indonesia menghasilkan 0,8 kg sampah perorang atau setara dengan 189 ribu ton sampah/hari. Dari jumlah tersebut $15 \%$ berupa sampah plastik (Arico \& Jayanthi. 2017). Harian Kompas pertanggal 19 Agustus 2018 menuliskan bahwa berdasarkan data dari Asosiasi Industri Plastik Indonesia dan Badan Pusat Statistik, sampah plastik di Indonesia mencapai 64 juta ton/tahun dan sebanyak 3,2 juta ton merupakan sampah plastik yang dibuang ke laut. Sampah plastik yang masuk ke laut dapat terbelah menjadi partikel-partikel yang kecil.
Partikel ini disebut mikroplastik dan merupakan salah satu sumber pencemaran di lingkungan laut. Mikroplastik ini dapat termakan oleh hewan di laut termasuk ikan yang selanjutnya dapat terkonsumsi oleh manusia.

Salah satu konsep yang diperkenalkan dalam mengelolah limbah termasuk limbah berbahan plastik dan sampah plastik adalah 3R (Reuse, Reduce, Recycle) (Raharjo et al. 2014). Penerapan konsep 3R di Indonesia telah banyak diaplikasikan di berbagai daerah dan terintegrasi dengan program bank sampah. Reuse berarti memanfaatkan kembali limbah atau sampah sesuai fungsinya sebelum dibuang. Contohnya botol kemasan dapat digunakan lagi untuk fungsi lain seperti dapat diisi ulang atau dijadikan pot tanaman untuk tujuan penghijauan. Reduce adalah mengurangi pemakaian atau konsumsi barang atau bahan yang dapat menimbulkan limbah atau yang sulit didegradasi. Hal ini dapat dilakukan dengan mengurangi konsumsi minuman botol yang berkemasan plastik sekali minum. Konsep recycle adalah dengan mendaur ulang limbah atau sampah menjadi suatu barang baru yang dapat digunakan kembali dan layak fungsi.

Praktek penerapan 3R sebetulnya sudah banyak dilakukan oleh masyarakat dan telah diinisiasi oleh akademisi melalui kegiatan pengabdian masyarakat. Konsep reuse misalnya dilakukan oleh masyarakat dengan memanfaatkan kembali botol minuman plastik bekas untuk 
menanam berbagai macam sayuran dengan sistem tanam veltikultur karena lahan yang sempit (Surtinah \& Nurwati. 2018). Sistem tanam secara hidroponik juga dapat memanfaatkan kembali botol minuman plastik bekas seperti yang dilakukan oleh masyarakat di Kabupaten Gunung Kidul (Sulistyawati et al. 2019).

Kelompok masyarakat yang sering mengkonsumsi minuman kemasan botol plastik adalah kalangan remaja, meskipun hingga saat ini penulis belum mendapatkan data angka tingkat konsumsi remaja terhadap minuman kemasan botol plastik. Dari hasil pengamatan seharihari, para remaja termasuk salah satu golongan yang banyak mengkonsumsi minuman ringan termasuk minuman berkemasan botol plastik. Hal ini mungkin disebabkan karena kepraktisan dalam mengkonsumsi minuman ringan tersebut. Untuk mengurangi limbah/sampah plastik yang berasaldariminumanberkemasan botol plastik, maka diperlukan tindak lanjut dengan berbagai strategi untuk meminimalisasi limbah/sampah botol plastik. Salah satu strategi yang dapat dilakukan adalah dengan mengedukasi remaja tentang pengetahuan dan sikap untuk mengurangi pemakaian botol plastik antara lain dengan konsep 3R. Remaja sebagai generasi muda dapat berperan aktif dalam memecahkan permasalahan masyarakat termasuk dalam menjaga keseimbangan lingkungan. Dengan membekali para remaja sejak dini tentang pengetahuan dan sikap serta keterampilan dalam mengelolah limbah/sampah botol plastik diharapkan akan lebih mudah dalam memecahkan masalah pencemaran lingkungan di Indonesia yang seharusnya dapat dimulai sejak usia dini.

Tujuan umum pelaksanaan pengabdian masyarakat dengan melibatkan siswa di Sekolah Menengah Pertama Muhammadiyah 1 Kota Ternate sebagai mitra adalah karena mitra sebagai remaja harus diperkenalkan sedini mungkin tentang konsep 3R dalam menjaga lingkungan hidup. Tujuan khusus kegiatan ini adalah (1) Meningkatkan pengetahuan dan sikap yang baik remaja terhadap konsep 3R dalam mengurangi (reduce) penggunaan botol minuman plastik, dan (2) Meningkatkan keterampilan siswa dalam menggunakan kembali (reuse) botol minuman plastik menjadi produk yang bermanfaat. Diharapkan setelah kegiatan ini dapat memberikan dampakyang nyata dalam mengurangi pencemaran lingkungan melalui pengurangan limbah/sampah plastik terutama plastik dari minuman kemasan.

\section{METODE PELAKSANAAN}

Pengabdian masyarakat ini dilaksanakan dalam tiga tahap. Adapun metode pelaksanaan adalah dengan sosialisasi melalui kegiatan penyuluhan dan pelatihan, dengan tahapan pelaksanaan sebagai berikut:

1. Sebelum kegiatan dilakukan, diawali dengan mengukur tingkat pengetahuan dan sikap para siswa di Sekolah Menengah Pertama Muhammadiyah 1 Kota Ternate. Pengetahuan dan sikap siswa 
yang diukur adalah pengelolaan limbah/sampah terutama sampah bersumber dari minuman kemasan botol plastik melalui konsep 3R. Tingkat pengetahuan siswa dan keberhasilan program sosialisasi dapat diketahui dari hasil evaluasi menggunakan cara pengukuran pretest dan posttest.

2. Melakukan sosialisasi melalui penyuluhan interaktif tentang manfaat dan pentingnya menjaga keseimbangan lingkungan untuk kelangsungan hidup dengan memperkenalkan konsep 3R.

3. Melakukan pelatihan pembuatan karya seni yang memanfaatkan limbah/sampah botol plastik bekas sebagai salah satu contoh penerapan konsep 3R.

Pada hari pertama, kegiatan diisi dengan memberikan sosialisasi menggunakan metode penyuluhan interaktif. Materi penyuluhan yang diberikan kepada siswa meliputi:

1. Gambaran beban lingkungan terhadap menggunakan botol plastik tidak dengan bijaksana, terganggunya kualitas dan keseimbangan ekosistem di wilayah perairan, dampak sosial dan kesehatan bagi manusia dengan terganggunya lingkungan dan isu terkini mengenai terganggunya ekosistem di laut Indonesia.

2. Memperkenalkan konsep 3R dalam praktek mengelolah limbah/sampah termasuk limbah botol plastik dan diberikan contoh penerapan konsep 3R, yaitu memanfaatkan kembali botol plastik, mengurangi pemakaian botol plastik dan mendaur ulang limbah botol plastik. Pada sesi ini juga ditunjukkan berbagai produk yang dihasilkan dari pemanfaatan limbah botol plastik.

Pada hari kedua kegiatan, dilaksanakanpelatihan membuatkarya seni dari limbah botol plastik. Bahanbahan dan peralatan yang dibutuhkan telah dipersiapkan sebelumnya oleh tim dengan melibatkan juga mahasiswa yang sedang melaksanakan kegiatan Kuliah Kerja Sosial (KKS). Untuk kegiatan ini para siswa dilatih keterampilannya dalam membuat karya seni yang memanfaatkan limbah botol plastik, yaitu bunga plastik dan pot plastik.

\section{HASIL DAN PEMBAHASAN}

Kegiatan ini dilaksanakan selama 2 hari yaitu pada tanggal 16-17 April 2019. Kegiatan diawali dengan melaksanakan pretest untuk mengukur tingkat pengetahuan dan sikap siswa tentang pengelolaan limbah/sampah dan konsep 3R.

Kuesioner dibagikan pada semua siswa sebanyak 54 orang yang berisi 10 pertanyaan tentang pengetahuan dan 10 pernyataan yang mengukur tentang sikap terhadap pengelolaan limbah/sampah plastik. Dari hasil pretest yang dibandingkan terhadap posttest, diperoleh hasil bahwa melalui kegiatan penyuluhan dapat meningkatkan pengetahuan siswa sebesar $37 \%$ dan sikap meningkat sebesar $40 \%$ seperti terlihat pada 
gambar 1 di bawah ini:

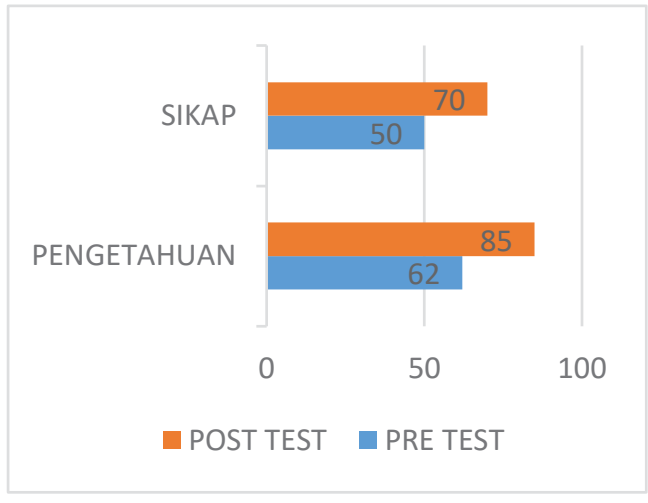

Gambar 1: Hasil pretest dan posttest tingkat pengetahuan dan sikap

Nilai rata-rata untuk pretest pengetahuan siswa adalah sebesar 62, sedangkan nilai rata-rata posttest untuk pengetahuan siswa meningkat menjadi 85. Persentase peningkatan pengetahuan siswa sebesar $37 \%$ dihitung dengan rumus:

$\%$ peningkatan $=\frac{(\text { posttest }- \text { pretest })}{\text { pretest }} \times 100 \%$

$\%$ peningkatan $=\frac{(85-62)}{62} \times 100 \%=37 \%$

Hasil pengukuran tingkat pengetahuansiswatentangpengelolaan sampah/limbah dari minuman kemasan botol menunjukkan bahwa kegiatan penyuluhan yang diberikan berhasil meningkatkan pengetahuan siswa di SMP Muhammadiyah 1 Kota Ternate.

Pengetahuan adalah hasil penginderaan manusia atau hasil tahu seseorang terhadap suatu objek (Notoadmodjo. 2012). Tingkat pengetahuan seseorang dapat dipengaruhi antara lain oleh pendidikan, sumber informasi/media informasi, sosial budaya dan ekonomi, lingkungan, pengalaman dan umur (Budiman \& Riyanto. 2013). Salah satu strategi untuk meningkatkan pengetahuan remaja terhadap konsep 3R dalam lingkup mengurangi dan mencegah pencemaran lingkungan adalah melalui sosialisasi dengan metoda penyuluhan sebagai salah satu sumber informasi siswa. Demikian pula dengan adanya pengalaman siswa selama mengikuti kegiatan pengabdian masyarakat ini dapat membentuk perilaku remaja sejak dini dalam menjaga lingkungan. Hasil kegiatan ini menunjukkan bahwa melalui penyuluhan di sekolah dapat meningkatkan pengetahuan siswa sesuai tujuan pengabdian masyarakat ini.

Untuk mengukur tingkat keberhasilan penyuluhan terhadap sikap siswa dalam pengelolaan sampah/limbah botol minuman kemasan plastik diukur sama seperti mengukur tingkat pengetahuan, yaitu dengan menghitung nilai rata-rata sikap siswa pada hasil pretest dan posttest. Nilai rata-rata untuk pretest sikap adalah 50, sedangkan nilai ratarata sikap pada hasil posttest adalah 70. Persentase peningkatan sikap siswa diperoleh sebesar $40 \%$ dengan rumus perhitungan:

$\%$ peningkatan $=\frac{(\text { posttest }- \text { pretest })}{\text { pretest }} \times 100 \%$

$\%$ peningkatan $=\frac{(70-50)}{50} \times 100 \%=40 \%$

Sikap adalah suatu bentuk reaksi atau respon terhadap suatu aspek dari lingkungan sekitar yang dapat mendasari seseorang dalam membentuk suatu perilaku yang baik. Perilaku remaja dalam merespon konsep 3R yang berhubungan dengan mengurangi dan mencegah pencemaranlingkungandapatdibentuk 
dari pengetahuan dan pengalaman yang baik. Dengan pengetahuan yang baik dan sikap yang positif yang dibentuk sejak dini termasuk pada remaja diharapkan dapat membentuk perilaku remaja yang baik dikemudian hari dalam mencegah dan mengurangi pencemaran lingkungan yang disebabkan oleh limbah/sampah plastik.

Suasana kegiatan sosialisasi pengelolaan sampah/limbah botol minuman kemasan plastik dan pengenalan konsep 3R di SMP Muhammadiyah 1 Kota Ternate seperti tampak pada gambar 2 di bawah ini:

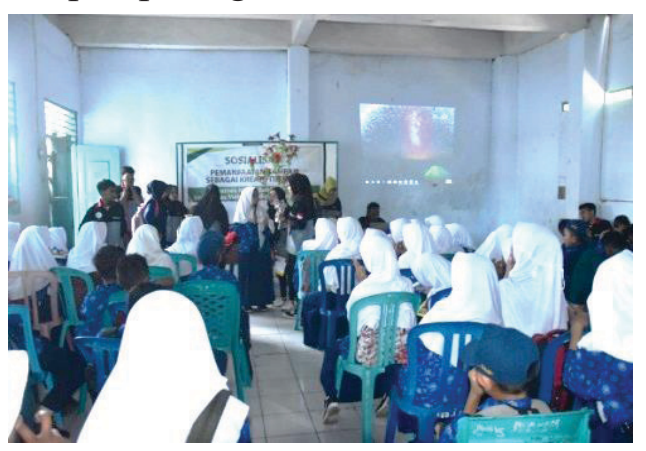

Gambar 2: Kegiatan sosialisasi melalui penyuluhan pada siswa SMP

Muhammadiyah 1 Kota Ternate

Kegiatan selanjutnya yang dilakukan adalah memperkenalkan beberapa contoh produk bermanfaat yang dapat dibuat dari limbah botol plastik. Beberapa contoh produk dari limbah/sampah botol plastik yang sudah dibuat antara lain berbagai jenis assesoaris wanita seperti gelang, kalung, bando, jepit rambut dan lain-lain (Doriza \& Putri. 2010) dan pemanfaatan kembali limbah/sampah botol minuman kemasan plastik sebagai media tanam tanaman obat keluarga sistem vertikultur (Sari et al. 2017), sebagai media tanam untuk sayuran (Surtinah et al. 2018) dan pembuatan sistem tanam hidroponik (Sulistyawati et al. 2019). Kegiatan melatih anak-anak dari keluarga tidak mampu untuk membuat kerajinan dengan memanfaatkan kembali botol plastik juga dilaksanakan di tempat wisata Baturaden (Febrianta \& Fauzan. 2017). Contoh produk yang dihasilkan dari kegiatan ini seperti terlihat pada gambar 3 .

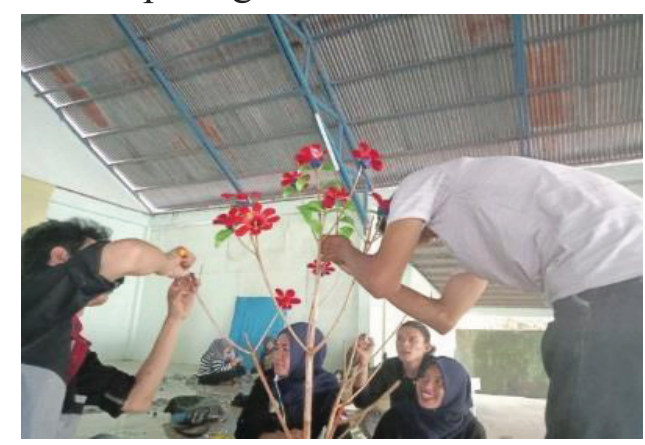

Gambar 3: Kegiatan pelatihan membuat karya seni dari botol plastik pada siswa SMP Muhammadiyah 1 Kota Ternate

Pengelolaan sampah juga dapat memberikan keuntungan lain dengan pembuatan bank sampah seperti yang dilakukan oleh masyarakat dusun Kluwet Kabupaten Sleman Yogyakarta (Utami, Indrasari \& Rezki. 2019).

Untuk mengetahui tingkat keberhasilan daripelaksanaan program pengabdian masyarakat ini maka perlu dilakukan pemantauan dan evaluasi. Pemantauan dilakukan selama pelaksanaan hingga selesai kegiatan dan dilanjutkan dengan evaluasi kegiatan. Selama pelaksanaan, para siswa terlihat antusias mengikuti kegiatan dari awal hingga akhir. Hal ini terlihat dari hasil evaluasi bahwa 
terjadi peningkatan nilai rata-rata pengetahuan siswa terhadap konsep $3 \mathrm{R}$.

Pada pelaksanaan pelatihan membuat beberapa kerajinan menggunakan botol minuman plastik melibatkan beberapa mahasiswa yang sedang melaksanakan KKS. Tujuannya adalah agar para mahasiswa juga dapat memberikan contoh dan terlibat langsung pada kegiatan pengabdian dan pemberdayaan masyarakat. Selain itu kegiatan ini dapat sebagai media mahasiswa untuk mempraktekkan ilmu yang telah diperoleh di bangku kuliah dan mahasiswa dapat melatih kemampuan softskills.

Agar dapatdiketahui keberhasilan kegiatan ini secara keseluruhan sesuai dengan tujuan yang ingin dicapai maka perlu dilakukan evaluasi. Evaluasi dilakukan dengan cara mendatangi kembali lokasi kegiatan beberapa hari setelah kegiatan dan berinteraksi dengan beberapa siswa. Hasil pengamatan menunjukkan bahwa siswa masih mampu menyebutkan beberapa materi penyuluhan dan bersikap positif untuk mengurangi konsumsi makanan maupun minuman kemasan plastik untuk mengurangi limbah/sampah plastik.

Mengingat pentingnya untuk mengurangidanmencegahpencemaran lingkungan dengan cara mengurangi limbah/sampah plastik untuk keberlanjutan kehidupan manusia serta karena semakin meningkatnya isu pencemaran lingkungan terutama di kawasan perairan, maka diperlukan keberlanjutan program pengabdian masyarakat ini yang akan dilaksanakan pada mitra siswa sekolah lainnya, para remaja dan komunitas masyarakat lainnya di kota Ternate.

\section{SIMPULAN}

Setelah dilakukan kegiatan pengabdian masyarakat ini, maka diperoleh hasil dengan kesimpulan sebagai berikut:

1. Melalui penyuluhan dapat meningkatkan pengetahuan siswa SMP Muhammadiyah 1 Kota Ternate sebesar 37\% dan sikap sebesar $40 \%$ terhadap pelaksanaan konsep 3R.

2. Siswa SMP Muhammadiyah 1 Kota Ternate telah meningkat keterampilannya dalam mengelolah limbah/sampah botol plastik menjadi suatu karya seni yang bermanfaat.

3. Secara keseluruhan, baik mitra maupun mahasiswa yang terlibat dalam program pengabdian masyarakat memiliki peran aktif dalam pencegahan pencemaran lingkungan melalui pengetahuan dan sikap yang baik serta keterampilan dalam memanfaatkan limbah/sampah minuman kemasan botol plastik menjadi suatu produk yang berguna.

\section{UCAPAN TERIMA KASIH}

Para penulis mengucapkan terima kasih kepada para mahasiswa peserta Kuliah Kerja Sosial Kelompok III Universitas Muhammadiyah Maluku Utara atas keikutsertaan dan partisipasinya dalam melaksanakan kegiatan pengabdian masyarakat ini. 
Ucapan terima kasih juga disampaikan kepada pimpinan sekolah SMP Muhammadiyah 1 Kota Ternate, para guru dan siswa sebagai mitra pada kegiatan ini.

\section{DAFTAR PUSTAKA}

Arico, S., \& Jayanthi, S. 2017. Pengolahan Limbah Plastik Menjadi Produk Kreatif Sebagai Peningkatan Ekonomi Masyarakat Pesisir. Martabe Jurnal Pengabdian Masyarakat. 1(1): 1-6.

Budiman \& Riyanto, A. 2013. Kapita Selekta Kuesioner Pengetahuan dan Sikap dalam Penelitian Kesehatan. Jakarta: Salemba Medika.

Doriza, S., \& Putri, V.U.G. 2014. Pemanfaatan Limbah Botol Plastik Melalui Pelatihan Wirausaha Produk Aksesoris Bagi Ibu Rumah Tangga. Sarwahita Jurnal Pengabdian Kepada Masyarakat. 11(2): 99108.

Ferdiani, R.D., Murniasih, T.R., Wilujeng, S., \& Suwanti, V. 2018. Penambahan Alat Produksi Guna Meningkatkan Produktivitas Pengrajin Keset. Jurnal Pengabdian dan Pemberdayaan Masyarakat. 2(1): 23-28.

Febrianta, Y., \& Fauzan, A. 2017. Pelatihan Pembuatan Kerajinan Berbahan Plastik Bekas. Jurnal Pengabdian dan Pemberdayaan Masyarakat (JPPM). 1(1): 2528.

Kompas.com. 2018. Indonesia Penyumbang Sampah Plastik Terbesar Kedua di Dunia. (2019, Agustus).Diunduh dari: https:// megapolitan.kompas.com/ read/2018/08/19/21151811/ indonesia-penyumbangsampah-plastik-terbesar-keduadi-dunia tanggal 1 April 2019.
Nurman, S., Ermaya, D., Hidayat, F., \& Sunartaty, R. 2019. Pemanfaatan Limbah Pertanian dan Peternakn Sebagai Pupuk Kompos. Jurnal Pengabdian dan Pemberdayaan Masyarakat (JPPM). 3(1): 5-8.

Notoadmodjo, S. 2012. Promosi Kesehatan dan Perilaku Kesehatan. Jakarta: Rineka Cipta.

Raharjo, S., Zulfan, M., Ihsan, T., \& Ruslinda, Y. 2014. Perencanaan Sistem Reduce, Reuse, dan Recycle Pengelolaan Sampah di Kampus Universitas Andalas Limau Manis Padang. Jurnal Teknik Lingkungan UNAND. 11(2): 79-87.

Rastono, A., Firgiyanto, R., Asih, P.R., Faustina, E., \& Megasari D. 2018. Pelatihan dan Pendampingan Teknologi Asap Cair Menggunakan Limbah Pertanian di Kecamatan Parengan, Tuban. Jurnal Pengabdian dan Pemberdayaan Masyarakat (JPPM). 2 (2): 279286.

Sari, D.M.M., Prasetyo, Y., \& Kurniawan, A. 2017. Metode Konversi Sampah Plastik Berupa Botol Plastik Bekas Melalui Budidaya Toga Dengan Sistem Vertikultur Yang Ramah Lingkungan. Gontor Argotech Science Jurnal. 3(2): 85-98.

Sulistyawati, Maulana, M., Tentama, F., Asti M., S., \& Sukesi, T.W. 2019. Pendampingan Pembuatan Sistem Hidroponik dan Pengolahan Sampah Organik. Jurnal Pengabdian dan Pemberdayaan Masyarakat (JPPM). 3(1): 77-82.

Surtinah \& Nurwati, N. 2018. Optimalisasi Pekarangan Sempit Dengan Tanaman Sayuran Pada Kelompok Ibu Rumah Tangga. Jurnal Pengabdian dan Pemberdayaan Masyarakat 
(JPPM). 2(2): 193-199.

Utami, E.R., Indrasari, A., \& Rezki,

S.B. 2019. Modernisasi

Pengelolaan Keuangan

dan Produk Bank Sampah.

Aksiologiya: Jurnal Pengabdian

Kepada Masyarakat. 3(1):

9-16. 